The International Journal of Digital Accounting Research

Vol. 8, N. 14, 2008, pp .23-44

ISSN: $1577-8517$

\title{
An Investigation into the Application of Continuous Online Auditing in the U.K. ${ }^{1}$
}

Kamil Omoteso. Leicester Business School, De Montfort University, Leicester, U.K. komoteso@dmu.ac.uk

Ashok Patel. Leicester Business School, De Montfort University, Leicester, U.K.

Peter Scott. Leicester Business School, De Montfort University, Leicester, U.K.

\begin{abstract}
As online technology continues to have a significant influence on business activities and due to the vital role auditing plays in the financial reporting systems, auditors are gradually adopting online technology in carrying out their tasks. While a number of studies have focused on the phenomenon, none of the few that have emanated from the UK is empirical in nature. This paper reports on an empirical investigation into the possible benefits and drawbacks of Continuous Online Auditing (COA) with a view to assessing its relevance to the future of both internal and external auditing. The findings indicate that the readiness of audit professionals and their clients to adopt COA is still a contentious issue. The paper concludes with some reflections on what the expansion of COA might mean.
\end{abstract}

Key words: Continuous Auditing, Continuous Online Auditing, Online Auditing, Real-time Auditing-oriented, financial reporting, information systems.

\footnotetext{
${ }^{1}$ The authors thank the participants at the $17^{\text {th }}$ National Auditing Conference held in Dublin, Republic of Ireland, 23-24 March 2007 for their helpful comments and suggestions on an earlier draft of this paper.
}

Submitted March 2008

DOI: 10.4192/1577-8517-v8_2

Accepted July 2008 


\section{INTRODUCTION}

The "big4" plus Grant Thornton and BDO International recently expressed the view that "billions of people around the world now have the ability to access information instantaneously - yet when it comes to financial reports, investors must wait for companies to publish data only once a quarter, every six months or annually... today's financial reports remain one-size-fits-all, and are not sufficiently accessible to many investors" (Global Vision, 2006:4). As a way of enhancing present day capital market stability, efficiency and growth, these top six firms proposed, among other advances, that a new business reporting model be developed to deliver relevant and reliable information in a timely way.

There has been an increase in the use of the Internet for disseminating financial information. US companies are currently taking the lead in this respect while their European counterparts are equally following suit. Use of the internet for reporting financial data results in the swifter and more timely provision of such information. Due to greater cost effectiveness and much improved convenience for all parties, current legislation allows companies to meet their statutory financial reporting obligations (including the auditor's report) to their shareholders by posting these reports on the company's website and advising shareholders that this has been done (Beattie and Pratt, 2003).

Otherwise referred to as real-time, concurrent or "lights-out" auditing, Continuous Online Auditing (COA) is a comprehensive electronic process that enables auditors to provide some degree of assurance on information simultaneously with, or very shortly after, the disclosure of that information. It covers all the three professional services commonly provided by independent auditors, that is, assurance, attestation and audit services (Rezaee et al., 2002), achieving this through real time accounting systems. Its key constituents are continuous audit of database applications, data capture procedures, systems audit and real time analytical procedures (Kogan et al., 1996).

COA can lead to the issuing of audit reports on a short interval basis (daily, weekly or as immediately as feasible). The Canadian Institute of Chartered Accountants (CICA, 1999) categorised auditors' reports in an online real-time situation into two: 
(i) the 'evergreen reports' which are usually made available whenever a user accesses an electronic site containing it: - dated at the time of user access; and

(ii) the 'reports on demand' which would only be accessible to a user on request rather than being automatically available.

COA can be useful as a modern auditing technique in two ways. It has both detective orientation (ex-post) and preventive orientation (ex-ante). The first orientation serves a similar purpose to the traditional audit of examining 'historical' records and books of account to derive audit evidence, whereas the latter serves as a barrier to the occurrence of errors and frauds through the use of ICT tools and techniques. This latter functionality is further enhanced through the design and use of appropriate artificial intelligence technologies to function as Continuous Intelligent Online Validation (CIOV) (Helms, 2002; Omoteso et al., 2003).

Under conventional audits, certain bottlenecks are encountered. These include the requirement of follow up, low expectation on control environment and frequent audit visits each time an audit opinion is required. However, under COA, control failures are identified and rectified as they arise, assessment of the strength of the control environment is improved and the audit opinion is always available whenever required (Handscombe, 2003).

As the UK is a technologically advanced economy and one of the very few countries that have played a significant role in the standardisation of modern audit practices, it would be an important endeavour to investigate the current and potential application of COA in the UK. Filling this research vacuum constitutes the main aim of this paper. The remainder of the paper is arranged under literature review, methodology and discussion of findings.

\section{LITERATURE REVIEW}

Kogan et al. (1999) identified the factors, institutions and technologies responsible for COA's development and the risks involved in its use and concluded that widespread availability of computer networking makes it possible to dramatically increase the frequency of periodic audits by redesigning the auditing architecture around online auditing. This pioneering exploratory work served as the springboard for further research efforts in the area as it highlighted a number of 
perspectives on the current and future implications of using the mechanism by practising auditors as well as the management of corporate organizations. Examples of such further research are Vasarhelyi (2002) on a series of research issues that might enhance the conceptualisation of modern assurance processes; Alles et al. (2002) on the feasibility and economics of continuous assurance; Orman's (2001) 'counting and periodic' audit strategies; and Pathak et al. (2005) on 'counting and time dependent' strategies for minimising the cost of continuous audit in assessing the economic feasibility of COA.

Rezaee et al. (2001) predicted that the rapid growth in technological advancement (e.g. Extensible Business Reporting Language (XBRL) being increasingly integrated into accounting software) might make online real-time preparation, publication, examination and extraction of financial information more widespread in the business world while Rezaee et al. (2002) advocated four fundamental requirements for auditors under a COA system: an increase in the auditor's knowledge of the client's business and industry; comprehensive understanding of the flow of transactions and control activities; employing a control-risk-oriented audit plan and developing their own software audit tools that are capable of auditing through the computer. It is interesting to note that in line with Rezaee et al.'s (2001) prediction, over 40,000 companies across the globe currently use XBRL (Global Vision, 2006).

Higson (2002) predicted that COA would possibly come to represent the fifth audit generation following Davis's (1996) description of four audit generations (verifying transactions in the books; relying on systems; risk-based; investigatory) while Searcy and Woodroof (2003) suggested that COA would be able to take care of the wastages commonly associated with the traditional audit process. These include overauditing, delay in data accessibility, time delay, cumbersome process, errors and mistakes.

In the US, the Institute of Internal Auditors (IIA) Research Foundation's (2003) study indicated that internal auditors showed interest in continuous auditing even though they believed they lacked training, funds and skills to apply this technique. The IIA's study appears to be the only empirical work on COA to date.

All the studies discussed above attempted to explain the usefulness of COA and its likely future directions. In addition most of them were predictive and descriptive rather than empirical in nature and they are all based on an American 
techno-economic context. As a result of these observations, this paper reports on a study conducted to assess, through the collection of empirical data, COA's relevance and its likely future use from both an external and internal audit perspective within the UK's techno-economic context. It was carried out using the socio-technical systems theory as theoretical underpinning.

The socio-technical systems theory postulates the significance and distinctiveness of the role of human actors vis-à-vis other needs within an organization. The foundation of the theory is the proposition that there should be an optimization of both individual and task needs when designing work processes (Walton, 1999).

The belief of 'technological determinism' (whereby technology is assumed to play an overwhelmingly constructive role in determining the development of social structure and economy) is widely prevalent and leads to raising the expectations of an unattainable level of performance from auditors just because they use ICT for their audits. Otherwise known as the technological imperative paradigm, this school of thought posits that ICT is a material cause and a key driver of change that is able automatically to alter organizational structures and social contexts (Davis, 1989; Hiltz and Johnson, 1990).

On the other hand, current efforts by the proponents of 'social shaping of technology' and 'social construction of technology' paradigms are likely to shift the argument towards social appreciation of technology by grounding technology in its social surroundings and addressing the real context in which technology is situated. This school of thought perceives ICT to be a product of human action rather than an objective external constraint. It believes that the organization's social contexts are the main driving force in the adoption and use of ICT. This school insists that human actors within a social context (such as a business organization) determine the what, when, how, where and who regarding the utilization of ICT in organizational processes and procedures (Wynne, 1988).

However, neither of the two paradigms can sufficiently explain the impact of COA on auditors' work as electronic technologies continue to foster a symbiotic relationship with social forces and the borderline between the two continues to be blurred as this interaction grows. Hence, the only feasible paradigm remains a holistic one that advocates a proportionate balance between technology and social forces, the socio-technical systems theory, which this paper adopts. 


\section{METHODOLOGY}

The research design had to accommodate the reality of auditors' increasingly busy schedules which made it difficult to gain extended interaction with all the target and participating respondents. Hence, this study adopted a mixed method of questionnaire and in-depth semi-structured interview on a one-to-one basis. The questionnaire and the interview questions were designed and piloted to test their validity and reliability to ensure the provision of useful research data of sufficient quality.

Data collection took place during 2004. Letters were sent to the partners in charge of audit and assurance services as well as heads of internal audit departments in 96 organisations to invite their participation in the study. The table below summarises the breakdown of the organisations contacted and those that eventually participated in the study according to the nature of their areas of operation:

\begin{tabular}{|c|l|c|c|c|c|}
\hline & $\begin{array}{c}\text { Organisation's } \\
\text { Description }\end{array}$ & $\begin{array}{c}\text { Number of } \\
\text { Organisations } \\
\text { Contacted }\end{array}$ & \multicolumn{2}{|c|}{$\begin{array}{c}\text { Number of Organisations } \\
\text { that Participated in: }\end{array}$} & TOTAL \\
\hline 1 & $\begin{array}{l}\text { "Big4" Accounting } \\
\text { Firms }\end{array}$ & 4 & Questionnaire & Interview & \\
\hline 2 & $\begin{array}{l}\text { Other Accounting } \\
\text { Firms }\end{array}$ & 46 & 4 & 2 & $\mathbf{6}$ \\
\hline 3 & $\begin{array}{l}\text { Public Sector } \\
\text { Organisations }\end{array}$ & 26 & 9 & 12 & $\mathbf{1 2}$ \\
\hline 4 & $\begin{array}{l}\text { Corporate } \\
\text { Organisations }\end{array}$ & 20 & 6 & 2 & $\mathbf{1 0}$ \\
\hline TOTAL & & $\mathbf{9 6}$ & $\mathbf{3 1}$ & $\mathbf{5}$ & $\mathbf{3 6}$ \\
\hline
\end{tabular}

Table 1. Analysis of Participating Organisations 
A cascading approach was used in distributing the electronic version of the questionnaire in most of the the participating organisations. As a result of the above procedures, while it can be easily stated that 74 questionnaires were returned, it is not possible to determine the number actually distributed and the response rate. In addition to those who responded to the questionnaires, auditors at various levels were interviewed in the organisations that preferred to participate in interviews. Table 2 below presents a breakdown of frequency of responses from each type of participating organisation in each of the data gathering exercises.

\begin{tabular}{|l|c|c|c|c|}
\hline & \multicolumn{2}{|c|}{ Questionnaire } & \multicolumn{2}{c|}{ Interview } \\
\hline & Frequency & Percent & Frequency & Percent \\
\hline "Big4" & 24 & 32.4 & 7 & 41.2 \\
\hline Other Accounting Firms & 19 & 25.7 & 0 & 0.0 \\
\hline Public Sector Organisations & 21 & 28.4 & 5 & 29.4 \\
\hline Corporate Organisations & 10 & 13.5 & 5 & 29.4 \\
\hline Total & $\mathbf{7 4}$ & $\mathbf{1 0 0 . 0}$ & $\mathbf{1 7}$ & $\mathbf{1 0 0 . 0}$ \\
\hline
\end{tabular}

Table 2. Number of Responses from Participating Organisations

The data gathered through the tape-recorded semi-structured interviews were analysed based on the strength of the views, explanations and arguments obtained from interviewees. In addition, the data obtained through the relevant sections of the questionnaires were analysed through the use of SPSS to generate both univariate and bivariate analyses in the form of frequency tables and Spearman's rank correlation respectively. The latter is a non-parametric technique used for measuring linear association between two variables based on ordinal datasets (Hussey and Hussey, 1997). The open-ended parts of the questionnaire were analysed with the use of Microsoft Excel and Access.

The frequency tables were also used for the analysis of responses across the scale for each question by calculating a Weighted Average Score (WAS) - with a view to determine an overall position in response to the question. The Likert scales were assigned a score of 1, 2, 3, 4 and 5 respectively for options ranging from, for 
example, Strongly Disagree (1) to Strongly Agree (5). The frequency of responses on each scale was multiplied by the weighting factor (e.g. $10 \times 1+20 \times 2+25 \times 3$ $+15 \times 4+12 \times 5=245$ ) divided by the total frequency of responses for the question (i.e. $10+20+25+15+12=82$ ) giving a WAS of 245/82 $=2.99$ which indicates a mid-position with no particularly strong opinion on the question) to determine the relative strength of agreement or disagreement with a particular proposition. The further towards either end of the scale the result of the above calculation, the greater the overall strength of opinion among the respondents, thereby providing a useful indicator for analysis.

Some respondents left a number of questions unanswered and these were excluded outright from the analysis of the questions concerned.

\section{Analysis and Discussion of Findings}

As discussed earlier, COA is an emerging auditing technique that could bring about a great deal of ease and effectiveness to the modern audit particularly with the increase in the use of online real-time mechanisms for business transactions and financial reporting systems. This section presents the study's findings divided into the benefits, drawbacks and potential usefulness of COA.

\section{Benefits of COA}

An open ended question was asked on the possible ways in which COA could enhance audit effectiveness and was answered by 45 questionnaire respondents (60.8\% of the total questionnaire respondents). The following is the list of responses to the question in order of respondents' aggregate prioritisation:

1. Quick discovery and investigation of errors and fraud.

2. Reduction of post year end intensive work level.

3. Time saving.

4. Adequacy, sufficiency and reliability of audit evidence.

5. Timely feedback to clients and other users.

6. Assurance of data accuracy.

7. Instant capture of transactions and control breaches. 


\section{Makes review easier.}

The list above indicates that the most important area at the forefront of auditors' minds is COA's ability quickly to discover and investigate errors and fraud. As these two phenomena constitute a potential internal control problem which both internal and external auditors are always acutely aware of in their audit responsibilities, COA will make their task easier to carry out and reduce audit risks related to control and detection.

Similarly, although a number of areas were identified by interviewees as possible ways in which COA could enhance audit effectiveness, quick discovery of errors and fraud does stand out. The interview excerpts below from auditors with a "big4" firm indicate that COA could generate high powered instantaneous analysis of raw data which makes it possible to highlight problems early and to communicate the problems identified (e.g. internal controls deficiency) to management for prompt action.

"Yes, in both areas it gives the auditor a greater opportunity to analyse core information in its raw state when it is actually produced, rather than after the event. This gives the auditor a greater opportunity to spot problems as they happen, reducing the problems that the auditor and the client may have in the future. Besides, it ensures greater precision in testing”.

“...Through continuous monitoring, you can see a problem more quickly and you can stop it before it gets too far rather than coming at the end of the year. This could reduce audit risk".

Furthermore, responses to the open-ended question as summarised in the list above show that COA's ability to scrutinise transactions and accounting procedures as they occur through its continuous validation techniques reduces the usual intensive efforts required of auditors at the financial year end, ensures accuracy of data and exposes control breaches. In addition, COA's reporting style (which could be 'evergreen' or 'on demand') ensures a timely feedback to clients and other users of financial reports with respect to well-timed assurance. Therefore, COA could further strengthen users' confidence in the depth of auditors' work and the reports that are generated from their work as depicted in the following comment from an auditor from a "big4" firm: 
"COA would help to address some of the concerns the public have about the depth of the work carried out by auditors and the rigour of their work and it should reduce year end work and the usual pressure on teams at year-end"

Added to these advantages, interviewees are somewhat divided on the issue of who benefits more from the use of COA between internal and external auditors. Interestingly, a majority of the external auditors who commented on this issue think COA could be more beneficial to internal auditors because they are expected to be monitoring various internal control systems constantly throughout the financial year. Also, they believe COA will be less useful for the external auditors as COA might take up a lot of their own and the client's time in discussing the impact of issues on areas requiring judgment rather than compliance.

"From the internal audit perspective, it can change the focus of what the auditors do if they can get the required information on a more timely basis. However, from the external audit perspective, I'm less convinced there is much to achieve".

- A senior manager with a "big4" firm

"Yes for internal auditors because they require continuous auditing throughout the year. In terms of external audit, it is limited in use because, quite often, you need to speak with the clients especially when the issue affects audit judgments that require clients' explanations and views. But in terms of monitoring, yes".

- An auditor with a "big4" firm

However, some of the interviewees hold the view that COA is just as useful to the external auditor as it is to the internal auditor as a core aspect of the external auditor's work is risk and internal control assessments which most interviewees (internal and external auditors) believe COA strengthens. Moreover, the provision of SAS 500 (Considering the Work of Internal Audit) which permits and sets out the main criteria for external auditors to place reliance on internal auditors' work makes COA a relevant tool for both parties as their work quite often overlaps. This view is stressed in the following interview comment which also advocates that COA could possibly link together both internal and external audit processes to enhance overall control and assurance purposes. 
"I think it will be nice to have the internal and external audit process integrated through COA where they can work hand in hand. However, this might be compromising auditor independence".

- An assistant audit manager with a Local government

The point of view expressed above confirms the assertion of Alles et al. (2002) which stated that the more comprehensive COA becomes the closer the relationship between the auditor and the auditee and this tendency might threaten auditor independence.

\section{Drawbacks of COA}

In spite of COA's benefits enumerated above, from an open-ended question in the questionnaire, respondents were able to identify the following as possible weaknesses. Again, the list of responses to the question is given in the order of respondents' aggregate prioritisation.

1. Over reliance on COA at the expense of other assessment.

2. Might take away the element of judgment.

3. Down time or system bug.

4. May be too intrusive/clients' employees might be uncomfortable.

5. Might increase fraud if clients know the system.

6. Incorrect set up.

7. Reduces human contact.

8. Audit report might lose importance and effectiveness.

9. Might limit analyses and comparisons.

Similarly, some of the interviewees discussed potential weaknesses inherent in the adoption and use of this auditing technique. Some of their comments show that the readiness of audit professionals and their clients to adopt COA is still an issue requiring careful attention. Firstly, interviewees were concerned about the readiness of the profession from an educational point of view. For example, a response from an auditor with a "big4" firm states: 
"There is an inadequate awareness of the process by most auditors. There are perception issues around what would be done and we are uncertain as to how well prepared from a training point of view the profession is for the transition. In addition, there is the problem of readiness of the clients".

The second concern identified related to worries about over-reliance on the simple findings produced by COA when the auditor should have a wider and less restricted view of the evidence in front of them:

"Yes, limitations in terms of perception that the statistics might suffice for the auditor rather than the quality of information depending on the nature of what is being audited. There are certain things you can't purely automate".

- An IS audit manager with a "big7" bank

Finally, the inevitable expense and security implications would have to be considered:

"Cost to the clients who are always looking at it from a cost-benefit perspective. These costs include setting up cost, cost of training etc. Again, there is the danger of hacking into the systems and back-up requirements".

- An auditor with a "big4" firm

Also, in the words of an auditor with a "big4" firm as quoted below, there is the fear that COA might lack the flexibility of approach auditing always requires but rather tempt the auditor to be over reliant on automated procedures, whereas these procedures might not be able to detect actions relating to connivance.

"Auditors may become over-reliant on automated procedures to pick up errors and you may ignore other factors e.g. collusion to defraud".

It is remarkable to note that most of the identified weaknesses of COA are human-related (possible over-reliance, judgment concerns, setting up the system, reduced interactions with client's physical environment, possibility of fraudulent practices etc). Also, all the benefits of efficiency, effectiveness and increased visibility of processes obtainable from the technique (as discussed in the last section) are underpinned by human actions. In a nutshell, COA originated from humans and was designed by humans for humans. The best results are only realisable with an optimal and evolving mix of well-designed technologies and appropriately skilled human actors who can add value to technological prowess. 


\section{Potential Usefulness of COA}

The limitations identified earlier could be overcome through adequate awareness campaigns on the workings and benefits of COA. These awareness campaigns might be carried out by the professional bodies through the CCAB, by way of feature articles in their monthly journals/magazines, articles on success stories of COA, symposia, workshops and conferences as suggested by the interview excerpt below from an auditor with a "big4" firm.

"There is a need to generate awareness of how the process works, briefings for auditors and companies on the process and the impact it will have on their practice, getting some high profile successes and making the community aware of the benefits".

Also, audit regulatory authorities could be of help by issuing appropriate standards and guidance to make the practice of COA clear and unambiguous with regards to who does what and who takes what responsibility among the parties within the domain of corporate governance.

"Keeping the clients informed, giving them information on the system and establishing normal protection and care to prevent hacking”.

- An auditor with a "big4" firm

In addition, these problems could be overcome effectively by introducing COA while its degree of reliability remains intact, introducing management accounting controls and strengthening systems protection and care to prevent hacking.

"It would be useful if a degree of flexibility can be introduced to the system without compromising its integrity. For example, frequency of review being varied depending on the manager's decision on the appropriateness of such reviews".

- The chief internal auditor of a UK "big7" bank

Furthermore, certain questions in the questionnaires probed into the usefulness of COA in fraud prevention, detection and investigation as well as its decision usefulness to all the stakeholders. 


\begin{tabular}{|c|c|c|c|c|c|c|}
\hline & $\begin{array}{c}5 \\
\text { Strongly } \\
\text { Agree }\end{array}$ & $\begin{array}{c}4 \\
\text { Agree }\end{array}$ & $\begin{array}{c}3 \\
\text { Neither } \\
\text { Agree Nor } \\
\text { Disagree }\end{array}$ & $\begin{array}{c}2 \\
\text { Disagree }\end{array}$ & $\begin{array}{c}1 \\
\text { Strongly } \\
\text { Disagree }\end{array}$ & WAS \\
\hline $\begin{array}{l}\text { COA could help } \\
\text { me in fraud } \\
\text { prevention }\end{array}$ & $\begin{array}{c}5 \\
(8.6 \%)\end{array}$ & $\begin{array}{c}34 \\
(58.6 \%)\end{array}$ & $\begin{array}{c}15 \\
(25.9 \%)\end{array}$ & $\begin{array}{c}4 \\
(6.9 \%)\end{array}$ & $\begin{array}{c}0 \\
(0 \%)\end{array}$ & $\begin{array}{l}214 / 58 \\
=3.69\end{array}$ \\
\hline $\begin{array}{l}\text { COA could help } \\
\text { me in fraud } \\
\text { detection }\end{array}$ & $\begin{array}{c}6 \\
(10.3 \%)\end{array}$ & $\begin{array}{c}40 \\
(69.0 \%)\end{array}$ & $\begin{array}{c}11 \\
(19.0 \%)\end{array}$ & $\begin{array}{c}1 \\
(1.7 \%)\end{array}$ & $\begin{array}{c}0 \\
(0 \%)\end{array}$ & $\begin{array}{l}225 / 58 \\
=3.88\end{array}$ \\
\hline $\begin{array}{l}\text { COA could help } \\
\text { me in fraud } \\
\text { investigation }\end{array}$ & $\begin{array}{c}7 \\
(12.1 \%)\end{array}$ & $\begin{array}{c}37 \\
(63.8 \%)\end{array}$ & $\begin{array}{c}13 \\
(22.4 \%)\end{array}$ & $\begin{array}{c}1 \\
(1.7 \%)\end{array}$ & $\begin{array}{c}0 \\
(0 \%)\end{array}$ & $\begin{array}{l}224 / 58 \\
=3.86\end{array}$ \\
\hline $\begin{array}{l}\text { COA could } \\
\text { enhance the } \\
\text { decision usefulness } \\
\text { of financial } \\
\text { information to } \\
\text { shareholders/ } \\
\text { partners in my } \\
\text { organisation }\end{array}$ & $\begin{array}{c}9 \\
(15.5 \%)\end{array}$ & $\begin{array}{c}27 \\
(46.5 \%)\end{array}$ & $\begin{array}{c}19 \\
(32.2 \%)\end{array}$ & $\begin{array}{c}3 \\
(5.2 \%)\end{array}$ & $\begin{array}{c}0 \\
(0 \%)\end{array}$ & $\begin{array}{l}216 / 58 \\
=3.72\end{array}$ \\
\hline $\begin{array}{l}\text { COA could } \\
\text { enhance the } \\
\text { decision usefulness } \\
\text { of financial } \\
\text { information to } \\
\text { investment } \\
\text { analysts }\end{array}$ & $\begin{array}{c}5 \\
(9.1 \%)\end{array}$ & $\begin{array}{c}23 \\
(41.8 \%)\end{array}$ & $\begin{array}{c}24 \\
(43.6 \%)\end{array}$ & $\begin{array}{c}3 \\
(5.5 \%)\end{array}$ & $\begin{array}{c}0 \\
(0 \%)\end{array}$ & $\begin{array}{l}195 / 55 \\
=3.55\end{array}$ \\
\hline $\begin{array}{l}\text { COA could } \\
\text { enhance the } \\
\text { decision usefulness } \\
\text { of financial } \\
\text { information to } \\
\text { prospective } \\
\text { investors }\end{array}$ & $\begin{array}{c}5 \\
(9.4 \%)\end{array}$ & $\begin{array}{c}21 \\
(39.6 \%)\end{array}$ & $\begin{array}{c}24 \\
(45.3 \%)\end{array}$ & $\begin{array}{c}3 \\
(5.7 \%)\end{array}$ & $\begin{array}{c}0 \\
(0 \%)\end{array}$ & $\begin{array}{l}187 / 53 \\
=3.53\end{array}$ \\
\hline
\end{tabular}




\begin{tabular}{|c|c|c|c|c|c|c|}
\hline $\begin{array}{l}\text { COA could } \\
\text { enhance the } \\
\text { decision usefulness } \\
\text { of financial } \\
\text { information to the } \\
\text { tax authorities }\end{array}$ & $\begin{array}{c}5 \\
(8.9 \%)\end{array}$ & $\begin{array}{c}26 \\
(46.4 \%)\end{array}$ & $\begin{array}{c}22 \\
(39.3 \%)\end{array}$ & $\begin{array}{c}3 \\
(5.4 \%)\end{array}$ & $\begin{array}{c}0 \\
(0 \%)\end{array}$ & $\begin{array}{l}201 / 56 \\
=3.59\end{array}$ \\
\hline $\begin{array}{l}\text { COA could } \\
\text { enhance the } \\
\text { decision usefulness } \\
\text { of financial } \\
\text { information to the } \\
\text { employees of my } \\
\text { organisation }\end{array}$ & $\begin{array}{c}3 \\
(5.4 \%)\end{array}$ & $\begin{array}{c}25 \\
(45.5 \%)\end{array}$ & $\begin{array}{c}23 \\
(41.8 \%)\end{array}$ & $\begin{array}{c}4 \\
(7.3 \%)\end{array}$ & $\begin{array}{c}0 \\
(0 \%)\end{array}$ & $\begin{array}{l}192 / 55 \\
=3.49\end{array}$ \\
\hline $\begin{array}{l}\text { COA could } \\
\text { enhance the } \\
\text { decision usefulness } \\
\text { of financial } \\
\text { information to the } \\
\text { general public }\end{array}$ & $\begin{array}{c}3 \\
(5.3 \%)\end{array}$ & $\begin{array}{c}27 \\
(47.4 \%)\end{array}$ & $\begin{array}{c}24 \\
(42.0 \%)\end{array}$ & $\begin{array}{c}3 \\
(5.3 \%)\end{array}$ & $\begin{array}{c}0 \\
(0 \%)\end{array}$ & $\begin{array}{l}201 / 57 \\
=3.53\end{array}$ \\
\hline
\end{tabular}

Table 3. Frequency Table on COA's Perceived Usefulness

Responses to all the above nine questions each generated a WAS of between 3.49 and 3.88. This indicates that respondents tend to agree that COA could be of value to virtually all stakeholders including external auditors and their clients' internal auditors as well as the general public in terms of its investigation powers and the usefulness of the financial information provided. However, it is instructive to note that respondents perceived greater usefulness of COA to business owners with two-thirds agreeing or strongly agreeing as compared to perceptions of usefulness to external users such as analysts and prospective investors with only around half of the respondents agreeing to these propositions. This perception of greater usefulness of COA to internal management and users indicates a potentially heightened role for COA in corporate governance.

In addition, an attempt can be made to determine whether there is any link between respondents' level of ICT utilisation and their opinion on the usefulness and relevance of the COA technique through the use of correlations. The two questions selected for this purpose are: 
1. COA could enhance the decision usefulness of financial information to shareholders/partners in my organization.

2. COA could enhance the decision usefulness of financial information to the general public.

The reason for selecting these two questions is that the shareholders are the primary addressee of the auditor's report while any member of the general public might be considered to represent another form of stakeholder. Also, since the nine questions generated similar WAS (between 3.49 and 3.88 according to the last table), they would be expected to yield the same result when correlated with the same variable. These two questions are correlated with the question on respondents' level of ICT utilisation in comparison with manual techniques:

For my audit assignments, I utilise....

3

More ICT Techniques

Than Manual Techniques
More Manual Techniques

Than ICT Techniques
1

Equal Proportion of ICT and Manual Techniques

It is to be expected that the level of a respondent's ICT utilisation might influence his/her appreciation of COA's benefits more fully. Also, out of these nine questions the two above are considered most appropriate as the main addressees of an audit report are the shareholders and other stakeholders represented by the public.

The results of the correlation exercise indicate auditors' perception on the usefulness of COA is not a function of their level of ICT usage in their audit tasks as the analysis generates correlation coefficients of -0.09 and 0.01 as shown in the tables below. As the correlation coefficients fall into the \pm 0.01 to 0.14 , this indicates that there is no correlation perceivable or that any that might exist is negligible. Clearly, auditors in all sizes of firms and of both internal and external persuasions are convinced of the future relevance and usefulness of COA in the audit function. 


\begin{tabular}{|l|l|c|c|}
\hline \multicolumn{2}{|l|}{} & $\begin{array}{c}\text { COA could enhance the } \\
\text { decision usefulness of } \\
\text { financial information to } \\
\text { shareholders/partners }\end{array}$ & $\begin{array}{c}\text { I utilise More/Equal/ } \\
\text { Less ICT than manual } \\
\text { techniques for my audit } \\
\text { assignments }\end{array}$ \\
\hline $\begin{array}{l}\text { COA could enhance } \\
\text { the decision } \\
\text { usefulness of } \\
\text { financial information } \\
\text { to the partners/ } \\
\text { shareholders }\end{array}$ & $\begin{array}{l}\text { Correlation } \\
\text { Coefficient } \\
\text { Sig. (2-tailed) }\end{array}$ & 1.000 & -.093 \\
\hline $\begin{array}{l}\text { I utilise More/Equal/ } \\
\text { Less ICT than } \\
\text { manual techniques } \\
\text { for my audit } \\
\text { assignments }\end{array}$ & $\begin{array}{l}\text { Correlation } \\
\text { Coefficient }\end{array}$ & -58 & .489 \\
\hline
\end{tabular}

Table 4. Spearman's Rank Correlation - Level of ICT Use and Perceived Usefulness of COA to Business Owners

\begin{tabular}{|c|c|c|c|}
\hline & & $\begin{array}{l}\text { COA could enhance the } \\
\text { decision usefulness of } \\
\text { financial information to } \\
\text { the general public }\end{array}$ & $\begin{array}{l}\text { I utilise More/Equal/ } \\
\text { Less ICT than manual } \\
\text { techniques for my audit } \\
\text { assignments }\end{array}$ \\
\hline $\begin{array}{l}\text { COA could enhance the } \\
\text { decision usefulness of } \\
\text { financial information to } \\
\text { the general public }\end{array}$ & $\begin{array}{l}\text { Correlation } \\
\text { Coefficient } \\
\text { Sig. (2- } \\
\text { tailed) } \\
\text { N }\end{array}$ & $\begin{array}{c}1.000 \\
- \\
57\end{array}$ & $\begin{array}{c}.009 \\
.948 \\
56\end{array}$ \\
\hline $\begin{array}{l}\text { I utilise More/Equal/ Less } \\
\text { ICT than manual } \\
\text { techniques for my audit } \\
\text { assignments }\end{array}$ & $\begin{array}{l}\text { Correlation } \\
\text { Coefficient } \\
\text { Sig. (2- } \\
\text { tailed) } \\
\text { N }\end{array}$ & $\begin{array}{c}.009 \\
.948 \\
56\end{array}$ & $\begin{array}{c}1.000 \\
- \\
72\end{array}$ \\
\hline
\end{tabular}

Table 5: Spearman's Rank Correlation - Level of ICT Use and Perceived Usefulness of COA to General Public 
Since this is the first empirical research on the relevance and significance of COA to both internal and external auditors, these results can only be compared with the theoretical projections of previous studies. They are in harmony with Rezaee et al.'s (2001) forecast that COA would soon become more widely adopted to auditors with the current exponential growth in technological and online capabilities as well as Higson's (2002) prediction of COA being the fifth audit generation. This likely shift towards COA has implications for the audit profession.

\section{Implications of the Study for the Auditing Profession}

From the foregoing analysis and discussions, the following implications can be drawn for the auditing profession:

1. COA is capable of reducing errors and fraud as unusual transactions and transaction patterns are easily detected and flagged for necessary action and investigation. This reduces the scope of criticism leveled at audit in terms of not including fraud detection as part of its core responsibilities.

2. COA could enhance investors' and stakeholders' confidence in online financial reporting by providing close to real-time access to audited statements.

3. As a corollary of the above two points, COA could significantly contribute to reducing the audit expectations-performance gap.

4. COA ensures the continued relevance and necessity of the audit function as it draws audit practice closer to technological realities in the business world.

5. The adoption of COA could create more jobs in the profession as experts spanning diverse social and technical skills besides the auditing knowledge and skills would be required to develop, implement, monitor and maintain COA's installation and operations. On the other hand, these jobs could be claimed by other existing and emerging professions if organisations feel the need for these functionalities.

6. The "big4" plus Grant Thornton and BDO International emphasised the need for much more regular audits. Obviously, nothing could be more regular than a continuous audit, hence COA is a prime candidate to fulfill this role. If this is the future of auditing, there are implications for the long 
term training needs of the profession as well as the career progression and direction of those currently in the profession.

7. Ordinarily, while it might have been expected that COA would make the information generated more objective and more trustworthy, a key finding was that this may not be the case at all and, in fact, the technique is likely to impair auditor independence through over familiarity with the clients' systems and the need for auditors and their clients to work hand in hand. This finding supports Higson (2002) advocating the position that COA should be more appropriate for internal auditors.

This brings into consideration ICAS's vision of internal auditors carrying out all the detailed work with the external auditors performing the role of external assessors so that the bulk of their work is judgemental in nature (McInnes, 1993). Perhaps the same sense is conveyed by the respondents in identifying a major drawback of COA as the loss of judgement elements by its users. In the light of this finding, ICAS's advocacy of external auditors as assessors appears justified.

\section{CONCLUSION}

The current study has attempted to investigate current views on the application of COA in the UK. As has been seen, there are perceived advantages and disadvantages to the technique and its impact upon the results of individual audits and the audit profession as a whole. However, the current study has provided only a snapshot of views from this initial investigation. Further update studies need to be undertaken to determine how the profession's views and use of COA are developing and how they will be expected to develop over time and, due to the continuous rate of technological change, how the views and perceptions expressed above have changed in the intervening period. Such developments lend themselves much more readily to a longitudinal study and the current paper is just the first step in this process with the views and conclusions expressed here subject to reinterpretation in the light of future findings.

Another limitation in the current investigation is the uneven response rate from the profession as a whole. A much wider coverage of the profession's views from all sizes of firms and internal auditors involved across the industrial spectrum is required to provide a much fuller picture of the perceptions of the advantages and disadvantages of the COA technique and its application in the audit of financial 
results. Similarly, views on the aspects of organisations that are most likely to benefit from the introduction of COA are required together with views on those audit tasks that must remain within the realm of human judgement must also be gathered and tested against ongoing implementation of COA within organisations and audit tasks.

Views on what the implementation of COA means for the future development of the profession have largely been inferred from the findings. Again, the ongoing changes within audit organisations and audit departments need to be determined to evaluate the future shape of the profession together with the training and development of future auditors and the skills they will be required to possess and acquire through experience and formal instruction. The continued relevance of the McInnes (1993) study needs to be assessed in the light of actual events and whether the public practice arm of the profession will take on the role of assessor of the findings of internal audit as a result of the technological developments currently taking place. In addition, evaluation of the effect of these changes on the structure and organisation of the audit profession both internal and external can be considered so that the profession can put plans in place to meet these new structures and levels of organisation as they arise. Technology is here to stay and auditors need to keep up with the pace of change and the new innovations and opportunities that it offers. There are clear advantages to COA and it is up to the profession to harness these advantages while at the same time taking steps to mitigate the impact of the disadvantages identified here that will determine the eventual success or otherwise of the COA techniques available.

\section{REFERENCES}

ALLES, M.G.; KOGAN, A.; VASARHELYI, M.A. (2002): "Feasibility and Economics of Continuous Assurance", Auditing: A Journal of Practice and Theory, vol. 21 (1): 123-138.

BEATTIE, V.; PRATT, K. (2003): "Issues Concerning Web-Based Business Reporting: An Analysis of the Views of Interested Parties", British Accounting Review, vol. 35 (2): 155-187.

CICA (1999): Continuous Auditing. Canadian Institute of Chartered Accountants. Toronto. 
DAVIS, F.D. (1989): "Perceived Usefulness, Perceived Ease of Use and User Acceptance of Information Technology", MIS Quarterly, vol. 13 (3): 319-340.

DAVIS, J.T. (1996): "Experience and Auditors' Selection of Relevant Information for Preliminary Control Risk Assessments", Auditing, vol. 15 (1): 16-37.

GLOBAL VISION (2006): Global Capital Markets and the Global Economy: A Vision From the CEOs of the International Audit Networks. http://globalpublic policysymposium.com, accessed on 11/01/2007.

HANDSCOMBE, K. (2003): "Continuous Online Auditing: Practical Experiences", Proceedings of the European Auditing Research Network Symposium, Manchester, United Kingdom.

HELMS, G.L. (2002): "Traditional and Emerging Methods of Electronic Assurance", The CPA Journal, vol. 72 (3): 26-31.

HIGSON, A. (2002): "Continuous Reporting and Auditing: Conceptual Considerations", Proceedings of the 4th World Continuous Auditing and Reporting Symposium, Salford, UK, 18-19 April.

HILTZ, S.R.; JOHNSON, K. (1990): "User Satisfaction with Computer-Mediated Communication Systems”, Management Science, vol. 36 (6): 739-764.

HUSSEY J.; HUSSEY, R. (1997): Business Research: A Practical Guide for Undergraduate and Postgraduate Students, London: Macmillan, pp. 230.

Institute of Internal Auditors Research Foundation (2003): "Internal Audit Use of Continuous Auditing: Current Use and Future Potential", www.theiia.org/iia/ download.cfm?file $=493$, accessed on 14/03/2005.

KOGAN, A.; SUDIT, E.F.; VASARHELYI, M. (1996): "Implications of Internet Technology: On-Line Auditing and Cryptography", IS Audit and Control Journal, vol. 3: 42-48.

KOGAN, A.; SUDIT, E.F.; VASARHELYI, M. (1999): "Continuous Online Auditing: An Evolution”, Journal of Information Systems, vol. 1(3): 87-103.

MCINNES, W.M. (ed) (1993): Auditing into the Twenty-first Century: A Discussion Document by the Research Committee of ICAS. Edinburgh: Institute of Chartered Accountants of Scotland. 
OMOTESO, K.; PATEL, A.; SCOTT, P. (2003): “The Impact of the Auditor's Use of Information and Communication Technology Tools and Techniques on the Audit Expectations Gap", Proceedings of the British Accounting Association (SEAG) Conference, 8th September, London.

ORMAN, L.V. (2001): "Database Audit and Control Strategies", Information Technology and Management, vol. 2 (1): 27-51.

PATHAK, J.; CHAOUCH, B.; SRIRAM, R.S. (2005): "Minimizing the Cost of Continuous Audit: Counting and Time Dependent Strategies", Journal of Accounting and Public Policy, vol. 24: 61-75.

REZAEE, Z.; ELAM, R.; SHARBATOGHLIE, A. (2001): “Continuous Auditing: The Audit of the Future", Managerial Auditing Journal, vol. 16(3): 150.

REZAEE, Z.; SHARBATOGHLIE, A.; ELAM, R.; MCMICKLE, P.L. (2002): "Continuous Auditing: Building Automated Auditing Capability", Auditing: A Journal of Practice Theory, vol. 21(1): 147-164.

SEARCY, D.L.; WOODROOF, J.B. (2003): "Continuous Auditing: Leveraging Technology", The CPA Journal, vol. 73(5): 46-48.

VASARHELYI, M.A. (2002): "Concepts in Continuous Assurance" in Sutton, S.; Arnold, V. (eds): Researching Accounting as an Information Discipline, Florida: American Accounting Association.

WALTON, J. (1999): Strategic Human Resource Development, Essex: Pearson.

WYNNE, B. (1988): "Unruly Technology: Practical Rules, Impractical Discourses and Public Understanding”, Social Studies of Science, vol. 18:147-167. 